Portland State University

PDXScholar

Center for Urban Studies Publications and Reports

Center for Urban Studies

$1-2000$

\title{
Land Use and Growth Impacts from Highway Capacity Increases
}

Thomas W. Sanchez

Portland State University

Follow this and additional works at: https://pdxscholar.library.pdx.edu/cus_pubs

Part of the Transportation Commons, and the Urban Studies and Planning Commons Let us know how access to this document benefits you.

\section{Citation Details}

Sanchez, Thomas W., "Land Use and Growth Impacts from Highway Capacity Increases" (2000). Center for Urban Studies Publications and Reports. 11.

https://pdxscholar.library.pdx.edu/cus_pubs/11

This Working Paper is brought to you for free and open access. It has been accepted for inclusion in Center for Urban Studies Publications and Reports by an authorized administrator of PDXScholar. Please contact us if we can make this document more accessible: pdxscholar@pdx.edu. 


\section{Land Use and Growth Impacts from Highway Capacity Increases}

Thomas W. Sanchez

January 2000

Center for Urban Studies

College of Urban and Public Affairs

Portland State University

Portland, OR 97207-0751

(503) 725-4020

(503) 725-8770 FAX

http://www.upa.pdx.edu/CUS/

PORTLAND STATE UNIVERSITY SUPPORTS EQUAL OPPORTUNITY IN ADMISSIONS, EDUCATION, AND USE OF FACILITIES, PROHIBITING DISCRIMINATION IN THOSE AREAS BASED ON RACE, SEX, SEXUAL ORIENTATION, COLOR, RELIGION, NATIONAL. ORIGIN, HANDICAP, OR AGE. THIS POL.ICY IS IN ACCORD WITH STATE AND FEDERAL LAW. 


\title{
Land Use and Growth Impacts from Highway Capacity Increases
}

\begin{abstract}
This analysis examined the historical relationship between land use changes and the location of capacity increasing highway projects in the State of Oregon from 1970 to 1990. Aerial photography for 18 cities was used to delineate the extent of urban development in each time period. A geographic information system (GIS) was used to assemble the data. Using this data, a logit regression model tested the significance of geographic variables such as proximity to highway projects, land use zoning classification, city size, and other spatial characteristics. The analytical methods used in this study incorporated a set of commonly used techniques to assess highway impacts on urban development patterns. The results suggest that for the 18 selected cities, the spatial measures performed well in predicting the location of urban development from 1970 to 1990. In addition, the results of the logit regression model indicated that controlling for other location factors, urban development had not clustered along state high project corridors as was suspected.
\end{abstract}

\section{Introduction}

Similar to other states, Oregon has experienced significant rates of growth in and around its urbanized areas. The growth has not been limited to metropolitan areas, with many non-metropolitan cities having experienced new urban development resulting from population increases in the range of 4 to 9 percent annually between 1970 and 1997 (Center for Population Research and Census, 1998). In an attempt to manage growth impacts, Oregon instituted a statewide policy of urban growth boundaries (UGBs). These boundaries are used to contain and direct urban development and provide coordination between jurisdictions (Knaap and Nelson 1992).

As urban areas grow in size, road and highway construction projects are used to facilitate vehicular travel patterns. In the period from 1975 to 1995 , per capita vehicle miles traveled (VMT) increased by more than 50 percent within Oregon's Willamette Valley, with much of this increase being attributed to an increase in the number of single-occupancy commuters (Gregor 1998). The challenge has been to accommodate local and regional travel demand with highway projects while not encouraging dispersed development, especially at the urban fringe. It has been shown that, while new development generates demand for new transportation facilities, increased accessibility from new highway facilities can also induce urban development (Moore and Thorsnes 1994). In this dynamic relationship between 
transportation and land use it is not known, however, whether capacity improvements induce development directly, or indirectly through increased accessibility.

There is a simultaneous relationship between land development and the provision of transportation infrastructure. Transportation services must be available to provide access before land can be developed, but the demand for development also creates a demand for access, which in turn is typically responsible for the ultimate provision of transportation infrastructure. This simultaneity complicates any efforts to determine the effect of road improvements on land development, specifically because most road improvements are in response to growing demand.

\section{Literature Review}

The literature on the effect of transportation infrastructure on the development of land is large but reaches few definitive conclusions and provides little empirical guidance (Giuliano 1989; Bourne 1980). There is widespread acknowledgment that the provision of roads opens land up to development and that land close to road access points is more valuable than land further away. Relatively little analysis, has been done however, to determine whether the provision of roads is due to increased levels of development or simply due to the movement of economic activity that would have occurred in any case. Academic literature has analyzed the effect of road improvements on state and regional economic development, with the results helping to provide context for analyzing the effect of specific road improvements (Fisher 1997; Forkenbrock and Foster 1990; Rietveld 1994; Brooks, London, Henry, and Singletary 1993).

In 1998, the National Cooperative Highway Research Program (NCHRP) reviewed and summarized the literature on the effect of road development on land use (NCHRP 1998). Three types of induced growth effects were identified with respect to transportation projects: projects planned to serve specific land development, projects that stimulate complementary functions, and projects that influence intraregional land development location decisions. In the first category, development is planned prior to the road improvement and the improvement is integral to the land use development, e.g., road improvements providing access to a new regional shopping center. Such improvements allow land development to occur; but the development clearly causes the demand for the road, so the development is 
not directly induced by the road improvements. In the second case, the development directly serves activity associated with the improvement. The examples presented are "gas stations, rest stops, and motels at highway interchanges" (NCHRP 1998). This is activity that is to some extent induced by the existence of the road.

Hence, the effect of road improvements on land development is associated with two important factors. The overall level of growth and related deficiencies in the transportation system determine whether the road improvement is likely to influence the total level of economic activity and urban development. The effect of the road on improving access to specific areas then affects the relative likelihood of development there as opposed to other places.

The development of transportation infrastructure can have several effects on land development. The provision of transportation services is one of the key inputs into the productivity of a region and is likely to have a substantial effect on the overall level of development. On the other hand, each individual transportation improvement contributes to the overall level of development but also creates incentives for development to locate in specific areas. This is particularly evident in suburban areas that have high levels of radial access to central business districts as well as emerging employment concentrations at the urban fringe (Greene 1980; Erickson and Gentry 1985). A related concern is whether infrastructure can influence the type of development that is likely to occur, or more relevantly the density at which development is likely to occur.

The effect of road improvements on the distribution of land use activity has received much less statistical analysis than the impact on overall levels of economic development. In particular, there is little discussion of the effect that ready availability of accessible land has on the density of development. Anas et al. (1998) summarize the discussion, "Highly accessible land is still underpriced and hence is developed at inefficiently low density. So the resulting land use pattern is likely to be inefficiently dispersed (not clustered enough). It is more difficult to say if the pattern is also inefficiently decentralized (too spread out from the center)..." (Anas, et al 1998, 1457). The literature on this score relies heavily on the impact of land price on the density of development. Making land available for development is an 
increase in supply that reduces the price of such land. The lower price then induces lower density of development (for examples see Fare and Yoon 1981; McDonald 1981; or Jackson et al. 1984).

Following Mohring's (1961) early work on highway benefits, a wide range of analyses have been performed that measure the influence of transportation accessibility on land values (see De la Barra 1989; Pendleton 1963; and Alcaly 1976). Many of these studies focus on the effect of transportation investments on urban form while others use land value analyses for highway impact assessment purposes (Langley 1976, 1981; Adkins 1957). Researchers have also identified land value effects at the urban fringe which typically identify transportation improvements as having a significant relationship with growth pressures (Shonkwiler and Reynolds 1986; Shi, Phipps, and Golyer 1997). In these cases, land values are seen as a proxy indicator for potential land use development, where land prices will influence the type and intensity of development.

Previous efforts to quantify the impact of road improvements on land development have been very limited (Deakin 1989). Some studies have analyzed historical development trends in highway corridors to illustrate the clustering associated with highway improvements (Baerwald 1982; Hartgen and Li 1994). However, detecting and quantifying agglomeration economies for highway corridor improvements requires detailed historical land use information that until recently was not easy to assemble or analyze. In many cases, projections of the impact of road development, as required, for example, in a Draft Environmental Impact Statement, start with an assumption of a fixed amount of activity and travel, then try to determine the effect of the road improvement on travel times and other traffic conditions. Often there are statements that deteriorating travel conditions and rising congestion might prevent the expected level of development if road improvements are not made.

More recent studies try to identify likely land use impacts, but there is seldom any quantitative analysis of the effect that the road improvement is likely to have on the future development of land and subsequent demand for use of the road. To conduct such an analysis, it would be necessary to determine both the impact of the road improvement on the total amount of economic activity that would occur in a specific area and the allocation of that activity, both with and without the road improvement. Where the 
effect is largely a reallocation of activity, some method must be generated to evaluate the impact of the reallocation on the total supply of accessible land, and the effect of this supply change on the price of land and hence on density. Determining these effects is substantially complicated by the other policy factors that are likely to affect the ability to bring land into development, such as the availability of urban infrastructure, land use regulations, suitability of the land for development, and the other amenity characteristics of the land (such as views or access to recreation).

\section{Methodology}

The primary objective of this study was to identify the historical relationship between capacityincreasing state highway improvements and land use development patterns. The research assessed the induced land use effects of highway improvements on the conversion of vacant land to urban uses. To do this, historical trends in urban development patterns were examined using aerial photography and spatial analysis within a GIS. The methodology is similar to that of Chapin and Weiss (1962) who presented one of the first comprehensive, grid-cell based land development analyses. Similar to this study, Chapin and Weiss did not propose a predictive model; rather, they sought to describe factors influencing development patterns. Their model, however, was not longitudinal, as is the analysis presented here.

This investigation was part of a statewide focus that tracked development trends over a 20-year period for 18 selected cities in Oregon. Table 1 and Figure 1 show the 18 Oregon cities selected for the spatial analysis. The selected cities range in population size from 997 (North Plains) to 44,757 (Corvallis). These cities grew an average of 64.9 percent from 1970 to 1990 . This was significantly higher than the 35.9 percent increase realized by the State of Oregon over this same time period. The 18 cities shown represent 14 different counties, generally from the western portion of the state. In addition, 16 of the cities had identifiable highway projects. A set of spatial measures and land use characteristics were used as predictors of urban development activities related to highway capacity improvements. A logit regression analysis was then used to test the significance of these spatial measures in predicting the location of urban development. 
Table 1 Cities selected for spatial analysis

\begin{tabular}{llrrr}
\hline City & County & $\begin{array}{r}\text { Population } \\
1970\end{array}$ & $\begin{array}{c}\text { Population } \\
1990\end{array}$ & $\begin{array}{r}\text { \% Change } \\
\mathbf{1 9 7 0 - 1 9 9 0}\end{array}$ \\
\hline Albany & Linn & 18,181 & 29,540 & $62.5 \%$ \\
Aumsville & Marion & 590 & 1,650 & $179.7 \%$ \\
Bend & Deschutes & 13,710 & 20,447 & $49.1 \%$ \\
Canby & Clackamas & 3,813 & 8,990 & $135.8 \%$ \\
Central Point & Jackson & 4,004 & 7,512 & $87.6 \%$ \\
Columbia City & Columbia & 537 & 1,003 & $86.8 \%$ \\
Corvallis & Benton & 35,056 & 44,757 & $27.7 \%$ \\
Dallas & Polk & 6,361 & 9,422 & $48.1 \%$ \\
Grants Pass & Josephine & 12,455 & 17,503 & $40.5 \%$ \\
Hillsboro & Washington & 14,675 & 37,598 & $156.2 \%$ \\
Klamath Falls & Klamath & 15,775 & 17,737 & $12.4 \%$ \\
Madras & Jefferson & 1,689 & 3,443 & $103.8 \%$ \\
McMinnville & Yamhill & 10,125 & 17,894 & $76.7 \%$ \\
North Plains & Washington & 690 & 997 & $44.5 \%$ \\
Redmond & Deschutes & 3,721 & 7,165 & $92.6 \%$ \\
Sherwood & Washington & 1,396 & 3,093 & $121.6 \%$ \\
Troutdale & Multnomah & 1,661 & 7,852 & $372.7 \%$ \\
Woodburn & Marion & 7,495 & 13,404 & $78.8 \%$ \\
\hline
\end{tabular}

Source: Center for Population Research and Census, 1998

The spatial analysis was based on aerial photographs for a 20 year time period (1970 to 1990). Aerial photography at a 1:20,000 or 1:40,000 scale for these time periods was available from U.S. Department of Agriculture, Agricultural Stabilization and Conservation Service. A GIS was used to overlay the extent of urban development for the selected cities over time (derived from aerial photography) to determine the location of urban development. Historical highway improvement information was overlaid on urban growth patterns delineated from the aerial photos to examine the coincidence of changes in land use and changes to the highway system. The logit regression analysis was then applied to test for the significance of spatial characteristics that influence urban development patterns. In this case, the impact of highway project locations was of particular interest. 
Figure 1 Cities selected for the development trend analysis

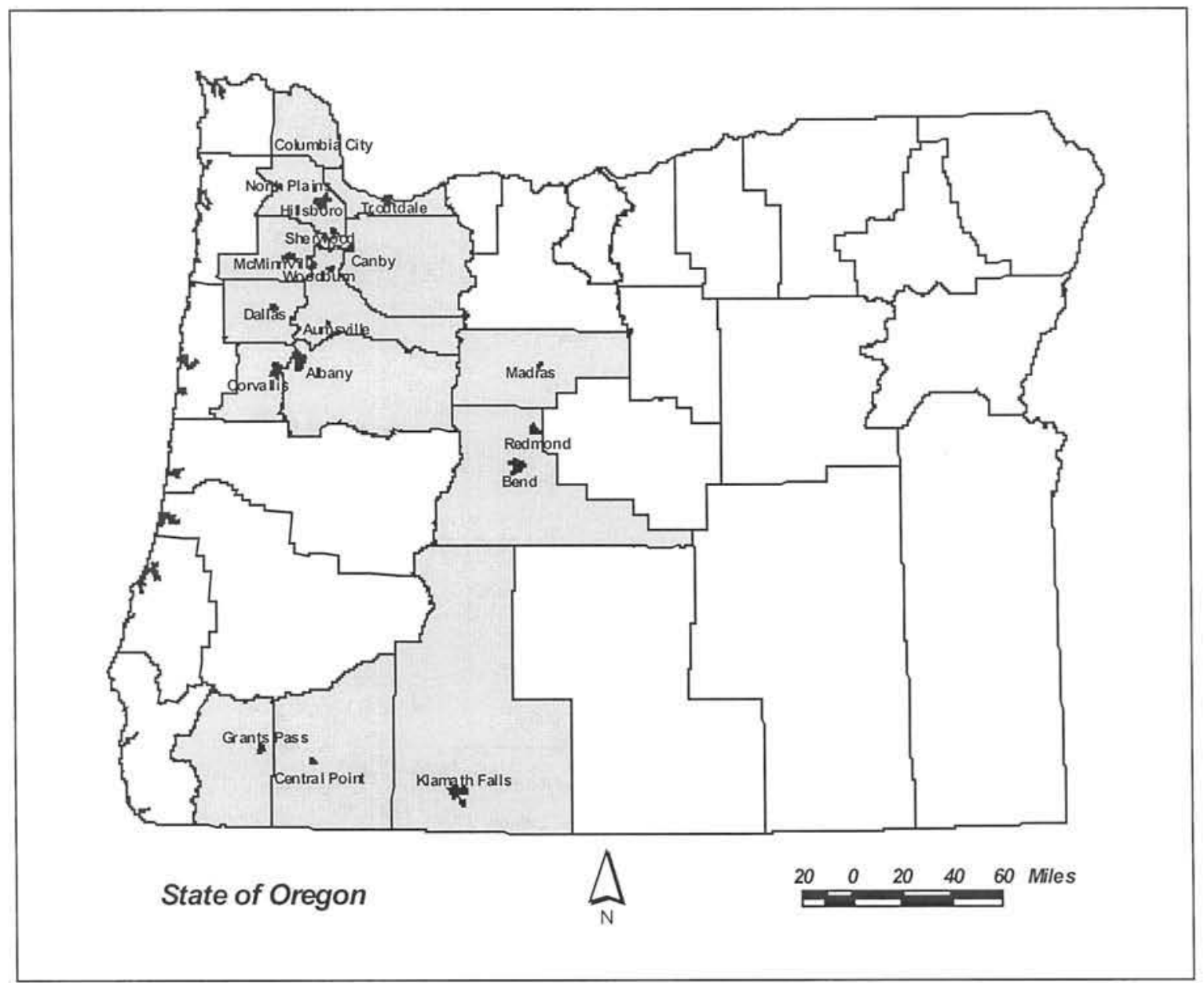

\section{Urban Change Detection Process}

The process used to convert aerial photography to urban development patterns for the 18 cities in the study included the following steps. Aerial photos obtained from the United States Department of Agriculture, Farm Service Agency, Aerial Photography Field Office (USDA-FSA-APFO) for 1970, 1980, and 1990 were used to estimate the extent of urban development over time. Areas were classified as being urban if development (residential, commercial, or industrial structures) was visible from the aerial photography. Areas located toward the center of urbanized areas that had dense vegetation, with no visible structures or impervious surfaces, were more likely to be considered urban because of their proximity to urban land uses than were similar areas at the urban fringe. For example, recreational open 
space within cities would generally be considered urban, while a farm at the urban fringe would not (although farmhouses and out-buildings would be considered urban). In addition, areas considered being at the urban fringe were those at the boundary of contiguous urban development. The urban fringe may or may not have coincided with a city incorporated limits or UGB. Because this analysis was concerned with conversion of land to urban uses, the physical characteristics dictated how areas were classified rather than legal or administrative designations.

\section{Results}

Based upon the estimates of urbanized area from the aerial photography, it was evident that significant urban development had occurred in nearly all of the 18 selected cities (see Table 2). For each of the cities, the analysis of land use change was limited to the areas up to 1 mile outside of the 1990 incorporated limits. A 1-mile buffer was used so that growth outside of city limits that was still geographically related to each city would also be included. In this way, discontiguous development was included while excluding areas that may not have been influenced by growth-inducing activities associated with the city. On average, for the 18 selected cities, rates of change were over twice as high during the period from 1970 to 1980 compared to the period from 1980 to 1990 . For the 20 -year period from 1970 to 1990 these cities expanded at an average rate of 72.2 percent. This rate corresponded to an average annual conversion of approximately 96.5 acres per city.

High rates of urbanization were not limited to cities that were small in geographic size. While smaller communities like Aumsville, Sherwood, and Troutdale more than doubled in urbanized area, larger communities like Albany, Hillsboro, and McMinnville did so as well. City population size and the rate of urban development from 1970 to 1990 exhibited a relatively weak, negative correlation $(\mathrm{r}=$ $0.232)$. 
Table 2 Rates of urban development for the selected cities (within 1990 city limits)

\begin{tabular}{|c|c|c|c|c|c|c|}
\hline City & $\begin{array}{c}\text { Acres } \\
1970 \\
\end{array}$ & $\begin{array}{c}\text { Acres } \\
1980 \\
\end{array}$ & $\begin{array}{c}\text { Acres } \\
1990 \\
\end{array}$ & $\begin{array}{c}\% \text { Change } \\
70 \text { to } 80\end{array}$ & $\begin{array}{l}\% \text { Change } \\
80 \text { to } 90\end{array}$ & $\begin{array}{c}\% \text { Change } \\
70 \text { to } 90\end{array}$ \\
\hline Albany & 4,050 & 6,466 & 6,794 & $59.7 \%$ & $5.1 \%$ & $67.8 \%$ \\
\hline Aumsville & 106 & 250 & 311 & $135.8 \%$ & $24.4 \%$ & $193.4 \%$ \\
\hline Bend & 2,341 & 3,285 & 4,725 & $40.3 \%$ & $43.8 \%$ & $101.8 \%$ \\
\hline Canby & 874 & 1,224 & 1,286 & $40.0 \%$ & $5.1 \%$ & $47.1 \%$ \\
\hline Central Point & 843 & 923 & 1,061 & $9.5 \%$ & $15.0 \%$ & $25.9 \%$ \\
\hline Columbia City & 187 & 225 & 264 & $20.3 \%$ & $17.3 \%$ & $41.2 \%$ \\
\hline Corvallis & 4,217 & 5,116 & 5,599 & $21.3 \%$ & $9.4 \%$ & $32.8 \%$ \\
\hline Dallas & 1,139 & 1,464 & 1,571 & $28.5 \%$ & $7.3 \%$ & $37.9 \%$ \\
\hline Grants Pass & 2,977 & 3,216 & 3,749 & $8.0 \%$ & $16.6 \%$ & $25.9 \%$ \\
\hline Hillsboro & 4,736 & 5,282 & 8,920 & $11.5 \%$ & $68.9 \%$ & $88.3 \%$ \\
\hline Klamath Falls & 3,937 & 4,339 & 4,453 & $10.2 \%$ & $2.6 \%$ & $13.1 \%$ \\
\hline Madras & 617 & 678 & 768 & $9.9 \%$ & $13.3 \%$ & $24.5 \%$ \\
\hline McMinnville & 1,897 & 2,994 & 3,696 & $57.8 \%$ & $23.4 \%$ & $94.8 \%$ \\
\hline North Plains & 226 & 239 & 282 & $5.8 \%$ & $18.0 \%$ & $24.8 \%$ \\
\hline Redmond & 1,849 & 2,250 & 2,446 & $21.7 \%$ & $8.7 \%$ & $32.3 \%$ \\
\hline Sherwood & 354 & 662 & 774 & $87.0 \%$ & $16.9 \%$ & $118.6 \%$ \\
\hline Troutdale & 241 & 813 & 998 & $237.3 \%$ & $22.8 \%$ & $314.1 \%$ \\
\hline Woodburn & 1,227 & 1,522 & 1,783 & $24.0 \%$ & $17.1 \%$ & $45.3 \%$ \\
\hline
\end{tabular}

Comparing development rates around highway improvements by location of the improvement suggested that projects generally at or near city limit boundaries exhibited more land use conversion than did projects at or near UGBs. On average, 41.6 percent of grid cells within 1 mile of highway projects converted to urban land uses for projects near city limits compared to 31.4 percent for projects near UGBs. This can be partly explained by the fact that projects near city limits were closer to previously developed land than were projects near UGBs (see Table 3). This does suggest, however, that the location of capacity increasing highway projects was somewhat related to the location of urban land use conversions. 
Table 3 Proportion of grid cell changes by population size, growth rate, and location

\begin{tabular}{lcrrrrc}
\hline City & $\begin{array}{c}\text { \% Change } \\
<1 \text { mile }\end{array}$ & $\begin{array}{c}\text { \% Change } \\
>1 \text { mile }\end{array}$ & $\begin{array}{c}\text { \% Change } \\
\text { City }\end{array}$ & $\begin{array}{l}1990 \\
\text { Pop. }\end{array}$ & $\begin{array}{c}\text { Pop. } \\
1970-1990\end{array}$ & $\begin{array}{c}\text { Proiect } \\
\text { Location(s) }\end{array}$ \\
\hline Albany & $52.3 \%$ & $30.5 \%$ & $35.3 \%$ & 29,540 & $62.5 \%$ & CL/UGB \\
Aumsville & -- & -- & -- & 1,650 & $179.7 \%$ & -- \\
Bend & $43.5 \%$ & $10.0 \%$ & $24.5 \%$ & 20,447 & $49.1 \%$ & CL/UGB \\
Canby & -- & -- & -- & 8,990 & $135.8 \%$ & -- \\
Central Point & -- & -- & -- & 7,512 & $87.6 \%$ & - \\
Columbia City & $9.6 \%$ & $0.0 \%$ & $6.5 \%$ & 1,003 & $86.8 \%$ & CL/UGB \\
Corvallis & $34.1 \%$ & $16.6 \%$ & $21.4 \%$ & 44,757 & $27.7 \%$ & CL \\
Dallas & $27.6 \%$ & $9.6 \%$ & $15.5 \%$ & 9,422 & $48.1 \%$ & CL/UGB \\
Grants Pass & $45.2 \%$ & $30.1 \%$ & $35.6 \%$ & 17,503 & $40.5 \%$ & CL \\
Hillsboro & $50.5 \%$ & $22.7 \%$ & $31.5 \%$ & 37,598 & $156.2 \%$ & CL \\
Klamath Falls & $21.1 \%$ & $9.3 \%$ & $11.8 \%$ & 17,737 & $12.4 \%$ & CL/UGB \\
Madras & $32.6 \%$ & $10.9 \%$ & $16.7 \%$ & 33,443 & $103.8 \%$ & CITY \\
McMinnville & $30.2 \%$ & $23.1 \%$ & $24.9 \%$ & 17,894 & $76.7 \%$ & CL/UGB \\
North Plains & $29.6 \%$ & $12.1 \%$ & $24.5 \%$ & 997 & $44.5 \%$ & CL \\
Redmond & $27.2 \%$ & $4.4 \%$ & $14.2 \%$ & 7,165 & $92.6 \%$ & CL/UGB \\
Sherwood & $32.1 \%$ & $28.4 \%$ & $30.2 \%$ & 3,093 & $121.6 \%$ & CL \\
Troutdale & $42.4 \%$ & $15.0 \%$ & $22.9 \%$ & 7,852 & $372.7 \%$ & CL \\
Woodburn & $35.6 \%$ & $16.4 \%$ & $26.0 \%$ & 13,404 & $78.8 \%$ & CL \\
\hline
\end{tabular}

$\mathrm{CL}=$ near city limit, $\mathrm{UGB}=$ near urban growth boundary, $\mathrm{CITY}=$ within city limits

In addition to the total geographic extent of urban development for each of the 18 selected cities, the density of development and land usage was also seen as an important measure of urban development trends. Measures of increases in the physical size of a city did not provide an indication of how efficiently land was being used. For this reason, per capita rates of land consumption per person were compared for 1970 and 1990 (see Table 4). As shown, two-thirds of the selected cities experienced increases in population density for the 20-year period from 1970 to 1990 . Canby and Central Point had the largest gains in density at over two additional persons per acre of urbanized land. On the other hand, the population density for Bend decreased by slightly more than 1.5 persons per acre, and McMinnville decreased by about 0.5 persons per acre. Population densities increased on average by 0.31 persons per acre. 
Table 4 Population density, change from 1970 to 1990

\begin{tabular}{lrrrrrr}
\hline City & \multicolumn{1}{c}{1970} & \multicolumn{1}{c}{$\begin{array}{l}\text { P99 } \\
\text { Population }\end{array}$} & $\begin{array}{c}\text { Change } \\
\text { Population }\end{array}$ & $\begin{array}{c}\text { Persons/ } \\
\text { Acre } 1970-1990\end{array}$ & $\begin{array}{c}\text { Persons/ } \\
\text { Acre 1990 }\end{array}$ & $\begin{array}{c}\text { Change } \\
1970-1990\end{array}$ \\
\hline Albany & 18,181 & 29,540 & $62.5 \%$ & 4.489 & 4.348 & -0.141 \\
Aumsville & 590 & 1,650 & $179.7 \%$ & 5.566 & 5.305 & -0.261 \\
Bend & 13,710 & 20,447 & $49.1 \%$ & 5.856 & 4.327 & -1.529 \\
Canby & 3,813 & 8,990 & $135.8 \%$ & 4.363 & 6.991 & 2.628 \\
Central Point & 4,004 & 7,512 & $87.6 \%$ & 4.750 & 7.080 & 2.330 \\
Columbia City & 537 & 1,003 & $86.8 \%$ & 2.872 & 3.799 & 0.928 \\
Corvallis & 35,056 & 44,757 & $27.7 \%$ & 8.313 & 7.994 & -0.319 \\
Dallas & 6,361 & 9,422 & $48.1 \%$ & 5.585 & 5.997 & 0.413 \\
Grants Pass & 12,455 & 17,503 & $40.5 \%$ & 4.184 & 4.669 & 0.485 \\
Hillsboro & 14,675 & 37,598 & $156.2 \%$ & 3.099 & 4.215 & 1.116 \\
Klamath Falls & 15,775 & 17,737 & $12.4 \%$ & 4.007 & 3.983 & -0.024 \\
Madras & 1,689 & 3,443 & $103.8 \%$ & 2.737 & 4.483 & 1.746 \\
McMinnville & 10,125 & 17,894 & $76.7 \%$ & 5.337 & 4.841 & -0.496 \\
North Plains & 690 & 997 & $44.5 \%$ & 3.053 & 3.535 & 0.482 \\
Redmond & 3,721 & 7,165 & $92.6 \%$ & 2.012 & 2.929 & 0.917 \\
Sherwood & 1,396 & 3,093 & $121.6 \%$ & 3.944 & 3.996 & 0.053 \\
Troutdale & 1,661 & 7,852 & $372.7 \%$ & 6.892 & 7.868 & 0.976 \\
Woodburn & 7,495 & 13,404 & $78.8 \%$ & 6.108 & 7.518 & 1.409 \\
\hline
\end{tabular}

\section{Logit Regression Analysis}

In addition to the amount of land being converted to urban uses, this analysis was particularly concerned with whether conversions were related to the location of capacity-increasing state highway improvements. Typically the relationship between land use impacts and transportation facilities is a function of physical proximity and market demand. This analysis attempted to isolate the correlation between the location of urban land conversion and the location of highway improvements assuming that demand for urban land uses existed in each case. The analysis also controlled for other spatial measures that indicated the likelihood of land being converted from vacant to urban land uses. These measures are shown in Table 5. To account for nonlinear distance relationships, squared distances were included for each of the primary spatial measures. For example, along with the variable D_HIGHWAY (linear distance to the nearest highway) was D_H2, which was the squared linear distance to the nearest highway. 
Observations for all of the 18 cities were pooled with observations from different cities being distinguished by including the 1970 population and the 1970 to 1990 population growth rate for each. A logit regression model incorporating the land use characteristics and spatial measures tests the significance of proximity to highway projects as a factor in the rate of land use conversions. There were 42,035 total observations for the 18 cities (see Table 5 for descriptive statistics.)

Table 5 Logit regression model variables and descriptive statistics

\begin{tabular}{llrr}
\hline \multicolumn{1}{c}{ Measures } & \multicolumn{1}{c}{ Variable name(s) } & Mean & Std. Dev. \\
\hline Linear distance to nearest highway (mi.) & D HIGHWAY, D H2 & 0.907 & 0.758 \\
\hline Linear distance to UGB (mi.) & D UGB, D U2 & 0.477 & 0.411 \\
\hline Linear distance to city center (mi.) & D CENTER, D C2 & 2.301 & 1.096 \\
\hline Linear distance to nearest highway project (mi.) & D PROJECT, D P2 & 1.682 & 1.236 \\
\hline Within 1990 city limits (0, 1) & IN CITY & 0.270 & 0.440 \\
\hline Years since nearest highway project completion & YEARS & 3.320 & 3.500 \\
\hline Land zoned as commercial (0,1) & Z COM & 0.042 & 0.200 \\
\hline Land zoned as industrial (0, 1) & Z IND & 0.081 & 0.270 \\
\hline Land zoned as rural/agriculture/open space (0,1) & Z RUR & 0.450 & 0.500 \\
\hline Land zoned as single-family residential (0, 1) & Z SFR & 0.370 & 0.480 \\
\hline Land zoned as multi-family residential (omitted) & Z MFR & -- & -- \\
\hline 1970 city population (ln) & LNPOP70 & 9.169 & 0.995 \\
\hline 1970 to 1990 population growth rate & POPCHG & 0.824 & 0.941 \\
\hline Spatial lag & SPATIAL & $<0.001$ & 0.142 \\
\hline
\end{tabular}

\section{Logit Regression Results}

If the nearness to a highway project significantly affected accessibility and increased development potential, the coefficients for D_PROJECT were expected to be negative. This means that as the distance to a highway project increased, the likelihood of being urbanized should decrease over time. The unit of analysis was an overlay grid cell (approximately 5.75 acres - 500 feet on a side). A binary dependent variable (CHANGED) indicated whether any new development occurred in a grid cell between 1970 and 1990. While the change in the percentage of urban land area within each grid cell was estimated, the distribution of values tends to be bimodal with most of the grid cells experiencing either no change or 100 percent change. If a grid cell was completely urban in 1970 , it was not included in the 
regression equation. In addition, grid cells also had to be within the 1990 city limits or up to 1 mile outside of the city limits to be included.

The logit regression equations successfully predicted 84 percent of the locations of urban land use conversions for the 18 selected cities. Overall, all independent variables were statistically significant except for the industrial zone indicator (Z_IND - see Table 6). Only a small percentage of grid cells were zoned for industrial and commercial uses compared to single family residential and rural land uses. The direction and magnitude of the resulting coefficients for the spatial variables appear to be reasonable given the theoretical relationships. The likelihood of urban development declined with increasing distances from urban cores, highways, state highway projects, and UGBs. The likelihood of development declined more rapidly with increasing distance to highways than for state highway projects suggesting the importance of general highway access. The likelihood of development also increased slightly over time controlling for the distance to the nearest state highway project.

In terms of land use zoning classifications, land zoned for single-family residential and commercial land uses were more likely to be developed compared to land zoned as industrial or rural. This suggests that rural and agricultural designations have generally inhibited development while growth accommodating commercial and residential zones were associated with increases in urban land use activities. In addition, properties in larger cities (based on 1970 population) were more likely to be urbanized. On the other hand, controlling for changes in population size, rates of urban development declined as rates of population sizes increased from 1970 to 1990 . As would be expected, the variable controlling for spatial dependence was a significant predictor of land use change. 
Table 6 Logit regression results

\begin{tabular}{lrrrrrr}
\hline & \multicolumn{3}{c}{ Model 1 } & \multicolumn{1}{c}{ Model 2 } \\
\hline Variable & \multicolumn{1}{c}{ B } & S.E. & Exp(B) & \multicolumn{1}{c}{ B } & \multicolumn{1}{c}{ S.E. } & Exp(B) \\
\hline D_CENTER & -0.832 & 0.046 & 0.435 & -0.904 & 0.058 & 0.405 \\
DC2 & 0.104 & 0.009 & 1.109 & 0.090 & 0.012 & 1.094 \\
D_HIGHWAY & -0.763 & 0.053 & 0.466 & -0.703 & 0.062 & 0.495 \\
DH2 & 0.182 & 0.020 & 1.199 & 0.175 & 0.022 & 1.191 \\
D_PROJECT & -0.206 & 0.033 & 0.814 & -0.488 & 0.039 & 0.614 \\
DP2 & -0.016 & 0.009 & 0.984 & 0.048 & 0.009 & 1.049 \\
D_UGB & -0.742 & 0.078 & 0.476 & -0.293 & 0.099 & 0.746 \\
DU2 & 0.521 & 0.044 & 1.683 & 0.185 & 0.063 & 1.203 \\
IN_CITY & 0.703 & 0.029 & 2.020 & 0.926 & 0.034 & 2.523 \\
YEARS & 0.044 & 0.004 & 1.045 & 0.053 & 0.004 & 1.054 \\
Z_COM & 0.544 & 0.070 & 1.724 & 0.554 & 0.086 & 1.740 \\
Z_IND & -0.130 & 0.062 & 0.878 & -0.054 & 0.078 & 0.948 \\
Z_RUR & -0.928 & 0.058 & 0.395 & -0.895 & 0.071 & 0.409 \\
Z_SFR & 0.518 & 0.054 & 1.679 & 0.505 & 0.067 & 1.657 \\
SPATIAL & & & & 4.580 & 0.096 & 97.527 \\
LNPOP70 & 0.294 & 0.019 & 1.341 & 0.367 & 0.022 & 1.443 \\
POPCHG & 0.073 & 0.017 & 1.076 & 0.089 & 0.021 & 1.093 \\
Constant & -2.136 & 0.169 & 0.118 & -2.698 & 0.203 & 0.067 \\
\hline No. observations & 46,746 & & & 46,746 & & \\
-2 Log likelihood & 41257.7 & & & 31305.2 & & \\
Nagelkerke R ${ }^{2}$ & 0.296 & & & 0.393 & & \\
\hline
\end{tabular}

Note: All coefficients significant at $\mathrm{p}<.01$ except for $\mathrm{Z}$ IND

\section{Model Evaluation}

The resulting logit model was applied to one of the selected Oregon cities to illustrate the performance of the model. The City of Grants Pass had two state highway projects that qualified for the analysis. The first was a 1.5 mile widening from two to four lanes extending across the city limit boundary toward the UGB which was completed in 1975 . The other facility was a third river crossing through the urban area to connect an interstate (I-5) with a state highway completed in 1985 (see figure 2). These projects potentially increase access to land beyond city limits and possibly exerting development pressure at or near the UGB. 
There were 2,178 grid cells (12,523 acres or 19.6 square miles) analyzed for Grants Pass. Of these, 775 (35.6 percent or 4,456 acres) experienced urban development between 1970 and 1990. The logit model predicted that 697 (32.0 percent or 4,008 acres) would be developed (see figure 3), a difference of 448 acres between actual and predicted. The model successfully predicted 81.2 percent of the change. According to the model, 471 fewer acres would have been developed between 1970 and 1990 if the state highway improvements had not been constructed (see figure 4). Much of this development was anticipated through land use zoning regulations and should not be interpreted as negative land use impacts. Obvious areas of under-prediction occurred in the western portion of Grants Pass. A closer examination of land use characteristics in this area may uncover other factors that should be included in the land use change model.

Figure 2 Grants Pass: Actual land use change, 1970 to 1990

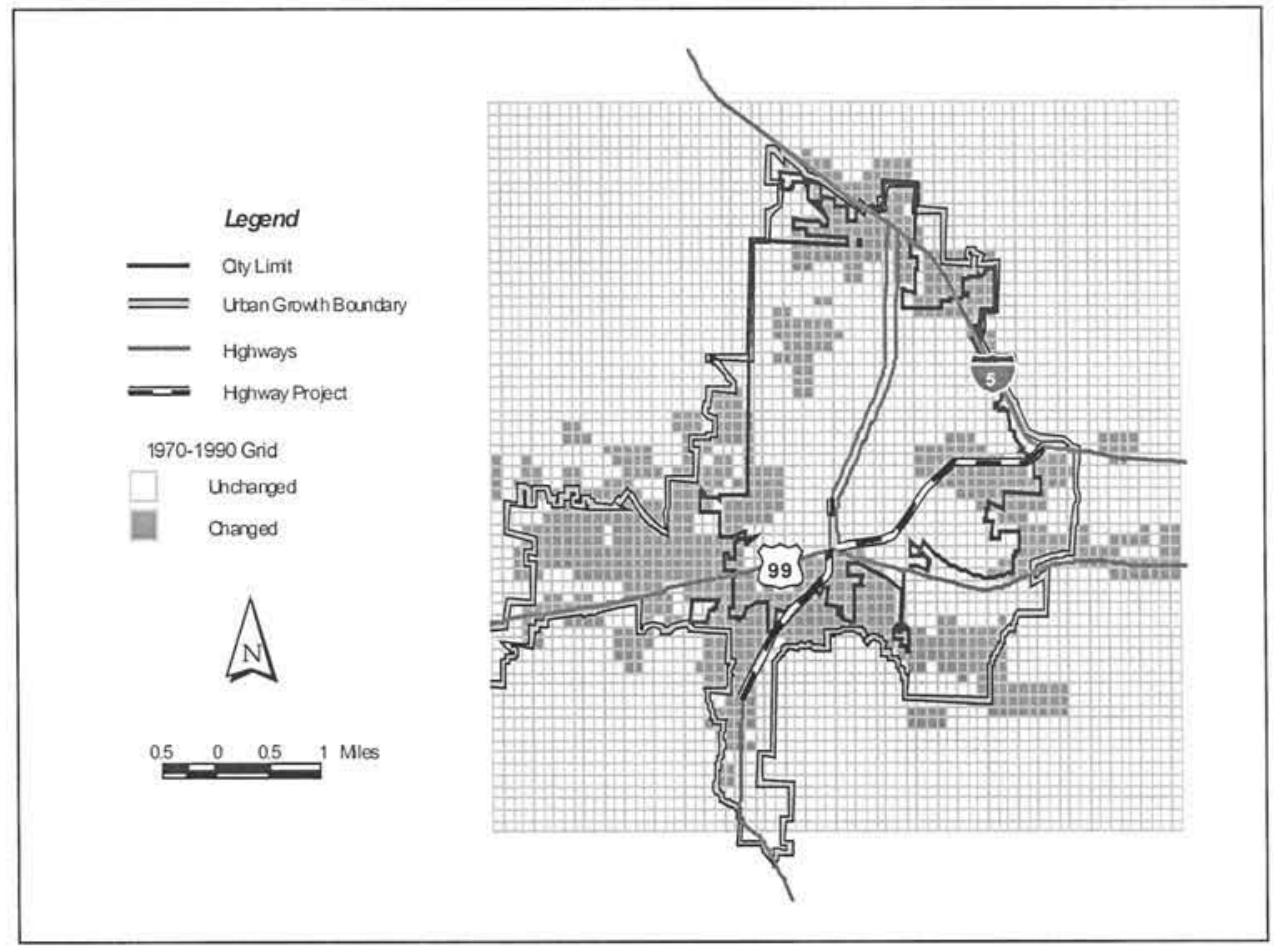


Figure 3 Grants Pass: Predicted land use change, 1970 to 1990

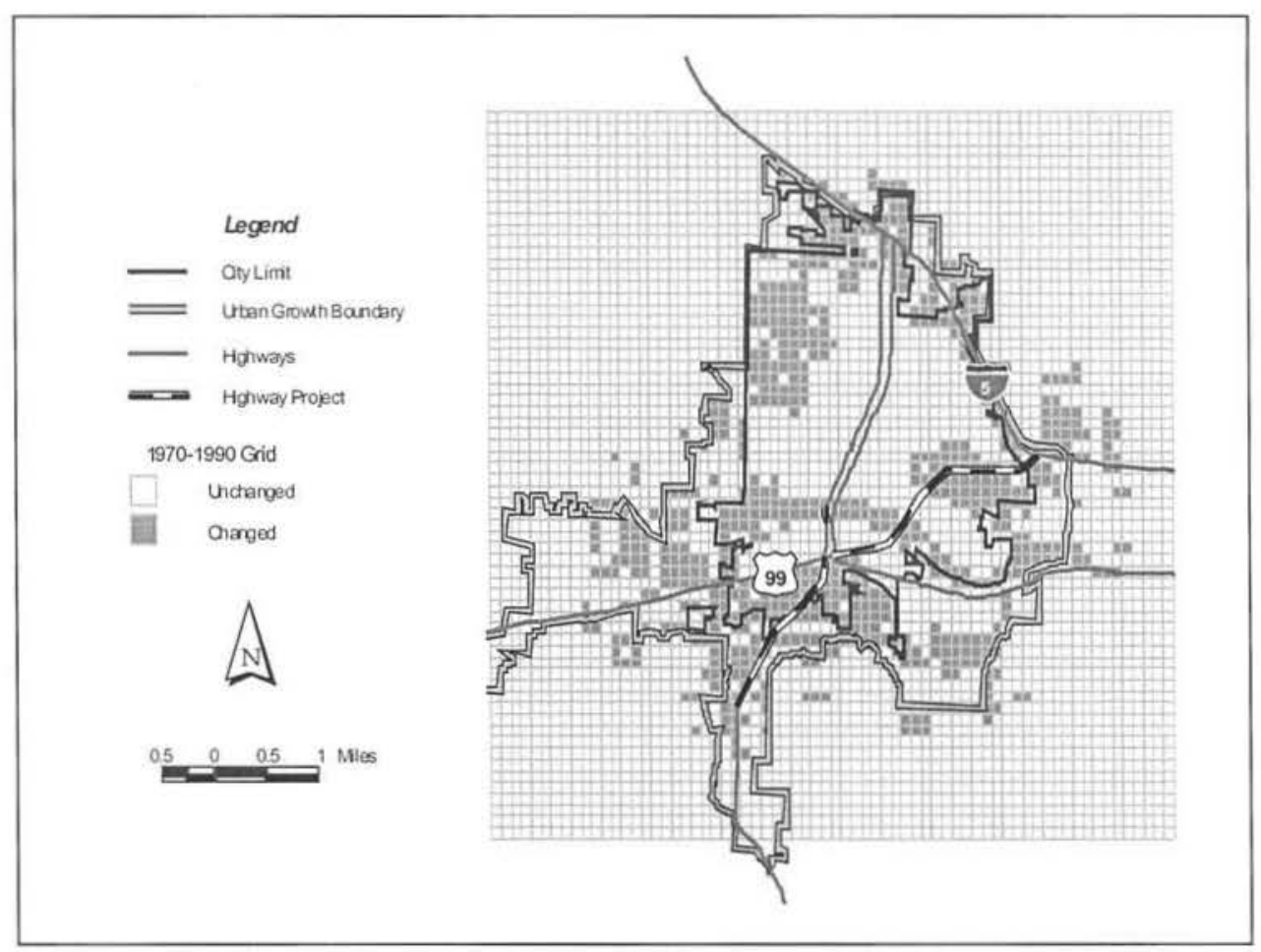

Figure 4 Grants Pass: Predicted land use change without highway improvements, 1970 to 1990

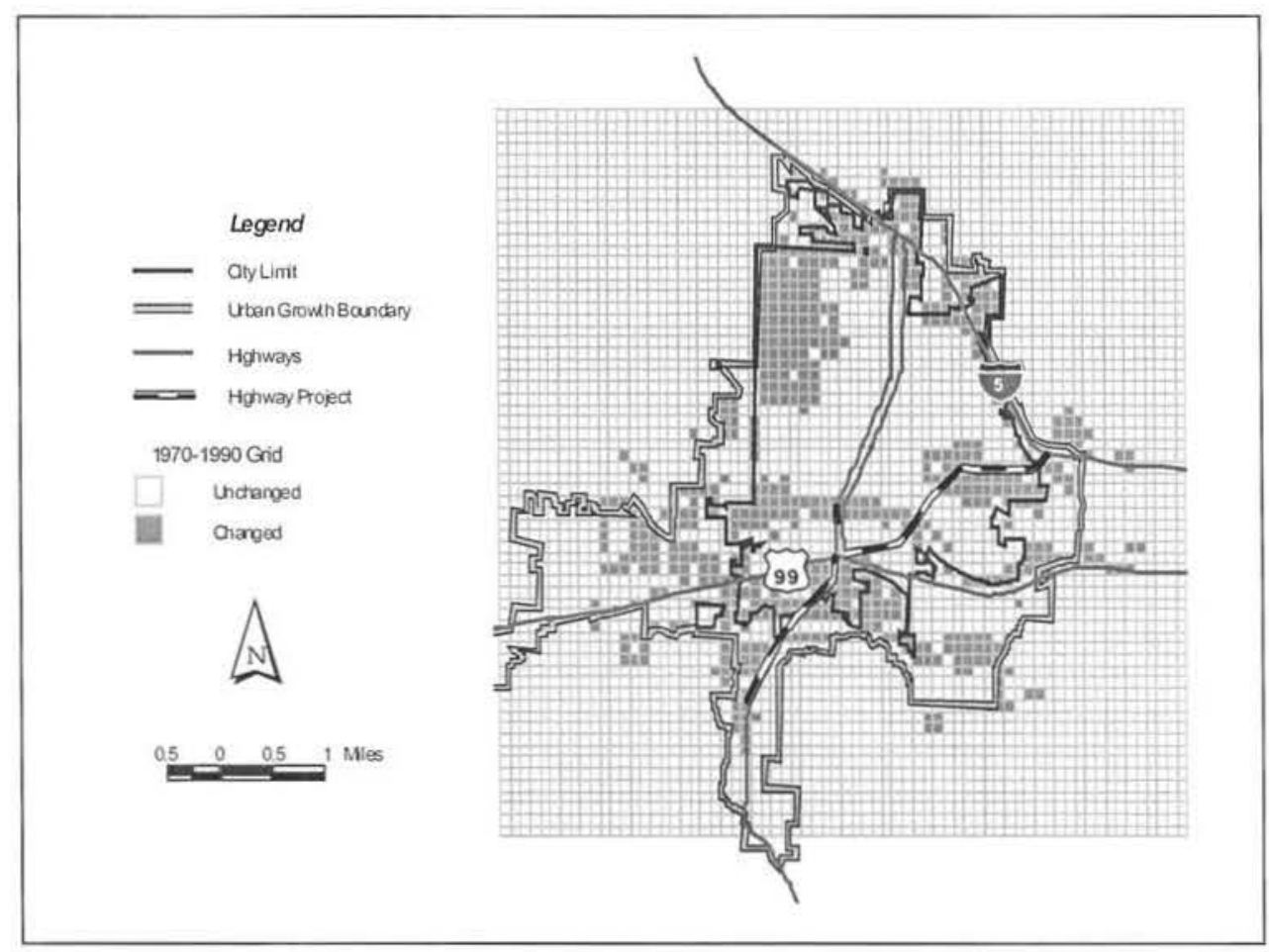




\section{Measurement Error}

The manual method of digitizing urbanized areas from aerial photographs involves a degree of error in a few different forms. Image distortion, edgematching errors, and image registration errors potentially contribute to either over- or under-estimation of total urbanized areas (see Aronoff 1991, Tellez and Servigne 1997). Because the analysis was performed at a relatively small geographic scale and because general rates of development were being reported, it is likely that the overall level of error in estimates of urbanized areas do not significantly affect the outcomes of the analysis.

It was also suspected that there was a lack of independence in the spatial data. A test for spatial autocorrelation confirmed this suspicion. For this reason an autoregressive procedure using generalized least squares regression was used to fit the data. A spatially lagged variable was generated using a simultaneous spatial autoregression (SAR) model (see Kaluzny, Vega, Cardoso, and Shelly 1998; Haining 1990). A second logit model was then fit that controlled for the spatial trend of residuals from the initial specification. In each case the spatially lagged model (including the variable SPATIAL) resulted in improved performance.

Measurement errors may also result from the method used to estimate accessibility measures. In this case the straight-line (Euclidean) distances from grid cell centroids to the nearest highway, highway project, and city center were used rather than the road network distance or travel time. In addition, the distances to the nearest highway and highway project were measured from the grid cell centroid to the nearest point along each line segment, rather than to the actual access point such as an on-ramp or interchange. This is significant because the ability to use a highway facility is influenced by the distance to an access point, which means that the variability of distance measures was affected by the type of highway (limited access, controlled access, unlimited access, etc.). It was probable that these measures did not have an adverse effect given the geographic scale of the analysis. More detailed network analysis would probably not add much variation to the relative accessibility measures for each of the grid cells. 


\section{CONCLUSIONS}

The analytical methods used in this study incorporated a set of commonly used techniques to assess highway impacts on urban development patterns. The results suggest that for the 18 selected cities, the spatial measures perform well in predicting the location of urban development from 1970 to 1990. This information provides a baseline for assessing the potential land use impacts of capacity increasing highway improvements.

Of most significance to this analysis, the results of the logit regression model indicated that controlling for other location factors, urban development has not clustered along state high project corridors. It can be assumed that these highway facilities had provided the requisite accessibility for urban development to occur elsewhere in the area. It should be noted that the analysis did not account for intraurban transportation network improvements administered by city or county jurisdictions. Non-highway transportation improvements may certainly improve circulation and congestion conditions, but not have the growth inducing impacts that major highway capacity increases tend to produce. In the case of the cities analyzed in this study, it appears that highway capacity increasing projects, which are typically a response to current or anticipated increase in travel demand, had not lead to direct and immediate land development activities.

Like other quantitative analyses of urban growth trends, this study could be enhanced with additional information about each of the urban areas. The study was limited by the availability and quality of the aerial photography, the precision of the urban area estimation techniques, the availability and reliability of the highway data, and the resolution and extent of city data. Additional information could also include the historic land use regulations and parcel information for each of the cities. Another important variable that should be included in subsequent analyses is the highway traffic volume. Additional vehicle traffic resulting from highway capacity increases is likely to be correlated with induced urban development demand. The location of other capital investments besides transportation facilities also influence development patterns. 
The model presented here provides a useful tool to analyze historical trends in land use development. Similar models can be utilized for highway impact assessment purposes - especially during the environmental impact assessment phases of project design. However, such a model cannot anticipate changes in political or economic environment of an urban area. Additional information on changes in local and state development policies as well as other indicators of development potential can be added to the model. 


\section{References}

Adkins, W.G. 1957. Land Value Impacts of Expressways in Dallas, Houston, and San Antonio, Texas. Highway Research Board, Bulletin 227, 50-65.

Alcaly, R.E. 1976. Transportation and Urban Land Values: A Review of the Theoretical Literature. Land Economics, 52, 42-53.

Anas, A., R. Arnott, and K.A. Small. 1988. Urban Spatial Structure. Journal of Economic Literature, 36, $1426-1464$

Aronoff, S. 1991. Geographic Information Systems: A Management Perspective. WDL Publications, Ottawa, Canada.

Baerwald, Thomas J. 1982. Land Use Change in Suburban Clusters and Corridors. Transportation Research Record, 861, 7-12.

Bourne, L.S. 1980. Alternative Perspectives on Urban Decline and Population Deconcentration. Urban Geography, 1, 39-52.

Brooks, K.R., J.B. London, M.S. Henry, and L.A. Singletary. 1993. Analysis and Simulation of Employment and Income Impacts of Infrastructure Investments in a State-Wide GIS Framework. Computers, Environment, and Urban Systems, 17, 129-151.

Center for Population Research and Census. 1998. Population of Counties and Cities in Oregon. Portland State University, http://www.upa.pdx.edu/CPRC/pbsrv1.html.

Chapin, F.S. and S.F. Weiss, eds. 1962. Urban Growth Dynamics: In a Regional Cluster of Cities, John Wiley and Sons, Inc., New York.

Deakin, E. 1989. Land Use and Transportation Planning in Response to Congestion Problems: A Review and Critique. Transportation Research Record, 1237, 77-86.

De La Barra, T. 1989. Integrated Land Use and Transport Modelling, Cambridge University Press, Cambridge.

Erickson, R.A. and M. Gentry. 1985. Suburban Nucleations. The Geographical Review, 75, 19-31.

Fare, R. and B.J. Yoon. 1981. Variable Elasticity of Substitution in Urban Housing Production. Journal of Urban Economics, 10, 369-374.

Fisher, R.C. 1997. The Effects of State and Local Public Services on Economic Development. New England Economic Review, March/April, 53-67.

Forkenbrock, D.J. and N.S.J. Foster. 1990. Economic Benefits of a Corridor Highway Investment. Transportation Research A, 24, 303-312.

Giuliano, G. 1989. Research Policy and Review 27: New Directions for Understanding Transportation and Land Use, Environment and Planning A, 21, 145-159.

Greene, D.L. 1980. Recent Trends in Urban Spatial Structure. Growth and Change, 11, 29-40. 
Gregor, B. 1998. Commuting in the Willamette Valley. Report prepared for Federal Highway Administration and Oregon Department of Transportation.

Haining, R. 1990. Spatial Data Analysis in the Social and Environmental Sciences. Cambridge University Press, Cambridge.

Hartgen, D.T. and Y. Li. 1994. Geographic Information Systems Applications to Transportation Corridor Planning. Transportation Research Record, 1429, 57-66.

Jackson, J.R., R.C. Johnson, and D.L. Kaserman. 1984. The Measurement of Land Prices and the Elasticity of Substitution in Housing Production. Journal of Urban Economics, 16, 1-12.

Kaluzny, S.P., S.C. Vega, T.P. Cardoso, and A.A. Shelly. 1998. S+ Spatial Stats, Springer, New York.

Kline, J.D. and R.J. Alig. 1999. Does Land Use Planning Slow the Conversion of Forest and Farm Lands? Growth and Change, 30, 3-22.

Knapp and Nelson

Langley, C.J. Jr. 1976. Adverse Impacts of the Washington Beltway on Residential Property Values. Land Economics, 52, 54-65.

Langley, C.J. Jr. 1981. Highways and Property Values: The Washington Beltway Revisited. Transportation Research Record, 812, 16-21.

McDonald, J.F. 1981. Capital-Land Substitution in Urban Housing: A Survey of Empirical Estimates. Journal of Urban Economics, 9, 190-211.

Mohring, H. 1961. Land Values and the Measurement of Highway Benefits. Journal of Political Economy, 69, 236-249.

Moore, T. and P. Thorsnes. 1994. The Transportation/Land Use Connection. Report Number 448/449, Planning Advisory Service, Chicago.

National Cooperative Highway Research Program (NCHRP). 1998. Guidance for Estimating the Indirect Effects of Proposed Transportation Projects. NCHRP Report 403. National Academy Press: Washington, DC.

Pendleton, W.C. 1963. Relation of Highway Accessibility to Urban Real Estate Values. Highway Research Record, 16, 14-23.

Rietveld, Piet. 1994. Spatial Economic Impacts of Transport Infrastructure Supply. Transportation Research A, 28, 329-341.

Shi, Y.J., T.T. Phipps, and D. Colyer. 1997. Agricultural Land Values under Urbanizing Influences. Land Economics, 73, 90-100.

Shonkwiler, J.S. and J.E. Reynolds. 1986. A Note on the Use of Hedonic Price Models in the Analysis of Land Prices at the Urban Fringe. Land Economics, 62, 58-63. 
Tellez, B. and S. Servigne. 1997. Updating Urban Database with Aerial Photographs: A Common Structuring Methodology. Computers, Environment, and Urban Systems, 21, 133-145. 